\title{
Stan rozwoju transportu intermodalnego w przewozach kolejowych kombinowanych w Polsce
}

\begin{abstract}
$W$ artykule przedstawiono udziat sektora kolejowego $w$ realizacji przewozów intermodalnych. Omówiono ilość i strukture przewozów w świetle oczekiwań unijnej polityki transportowej. Przedstawiono techniczne parametry infrastruktury kolejowej, warunkujace wdrożenie środków transportu kombinowanego oraz pokazano przyklady prac projektowych specjalnych wagonów do transportu kombinowanego.
\end{abstract}

\section{WPROWADZENIE}

Transport kombinowany jest szczególnym przypadkiem transportu intermodalnego, gdzie towar transportowany jest $\mathrm{w}$ tej samej jednostce ładunkowej lub pojeździe, przy czym zasadnicza część trasy odbywa transportem kolejowym, wodnym śródlądowym lub morskim. Maksymalnie krótkie odcinki początkowe i końcowe wykonywane są przez transport drogowy.

Transport kombinowany może stanowić jedno $\mathrm{z}$ narzędzi służących realizacji unijnej polityki transportowej, której podstawowym dążeniem jest zmniejszenie społecznych, środowiskowych i ekonomicznych kosztów transportu przy jednoczesnym utrzymaniu efektywności systemu. Szczegółowe cele polityki transportowej Unii Europejskiej ujęto w Białych księgach.

Pierwsza z 2001 roku [1] w zakresie dotyczącym transportu kolejowego jako priorytet wskazała jego rewitalizację oraz rozwój transportu intermodalnego. Biała księga z 2011 roku [2] zawiera wytyczne utworzenia jednolitego europejskiego obszaru transportu. Zgodnie $\mathrm{z}$ wytycznymi tego dokumentu należy:

- Opracować nowe wzorce transportu, pozwalające na transport większej liczby towarów i pasażerów za pomocą najwydajniejszych środków lub kombinacji takich środków.

- Przeprowadzić konsolidację znacznych ilości towarów przewożonych na duże odległości poprzez wprowadzanie rozwiązań multimodalnych opartych na środkach transportu wodnego i kolejowego jako warunek osiagnięcia wymaganych redukcji negatywnego oddziaływania na środowisko.
- Zachęcać do wyboru alternatywnych rozwiązań transportowych (transport kolejowy, wodny).

- Podnieść opłacalność dla przewoźników multimodalnego transportu towarów. Niezbędna jest skuteczna współmodalność. UE potrzebuje specjalnie zaprojektowanych korytarzy transportowych, optymalnych pod względem wykorzystania energii i emisji oraz minimalizacji wpływu na środowisko, a także atrakcyjnych ze względu na niezawodność, ograniczone zagęszczenie ruchu i niskie koszty operacyjne.

- Zapewnić zmianę strukturalną niezbędną do umożliwienia skutecznego konkurowania przez transport kolejowy oraz przejęcia większej proporcji transportu towarów na średnie i dalekie odległości. Niezbędne będą znaczne inwestycje pozwalające na rozszerzenie lub unowocześnienie przepustowości sieci kolejowej.

Wdrożenie powyższych wytycznych według założeń umożliwi realizację celów długoterminowych:

- Do 2030 r. $30 \%$ drogowego transportu towarów na odległościach większych niż $300 \mathrm{~km}$ należy przenieść na inne środki transportu, np. kolej lub transport wodny, zaś do 2050 r. powinno to być ponad $50 \%$ tego typu transportu.

- Stworzenie do 2030 r. w pełni funkcjonalnej ogólnounijnej multimodalnej sieci bazowej TEN-T, zaś do 2050 r. osiagnięcie wysokiej jakości i przepustowości tej sieci, jak również stworzenie odpowiednich usług informacyjnych. 
W tym kontekście wdrażanie w polski system transportowy systemów transportu kombinowanego kolejowo drogowego umożliwi realizację wytycznych Unii Europejskiej dla utworzenia jednolitego europejskiego obszaru transportu.

Nacisk na rozwój tego rodzaju transportu stanowi jeden czynników budujących jego przewage konkurencyjna. Transport drogowy generuje największe obciążenia ekonomiczne na które składają się koszty ekologiczne i społeczne. W stosunku do transportu wyłącznie drogowego, transport kombinowany proporcjonalnie do udziału transportu kolejowego wnosi jego proekologiczne, prospołeczne i ekonomiczne zalety. Poza proporcją udziału, poziom korzyści z wprowadzenia transportu kombinowanego zależy od wielu innych czynników. Do najistotniejszych należą: rodzaj napędu lokomotywy pociagu kombinowanego, rodzaj wagonów i ich maksymalna liczba w składzie, rodzaj silnika ciagnika drogowego, ładowność naczepy drogowej, pora roku, pora dnia, rodzaj terenu, zabudowa terenu oraz istniejąca infrastruktura kolejowa liniowa i punktowa.

W Polsce koszty destrukcyjnego oddziaływania transportu na środowisko stanowią 29\% kosztów zewnętrznych [9]. Składają się na nie koszty zanieczyszczenia powietrza, hałasu i zmian klimatycznych. Pozostałe $71 \%$ to koszty wypadków transportowych. Przeniesienie transportu na kolej spowoduje zmniejszenie kongestii a w konsekwencji liczby wypadków i ich kosztów.

\section{WIELKOŚĆ PRZEWOZÓW INTERMO- DALNYCH W POLSCE}

W polskim transporcie kolejowym dominuja przede wszystkim przewozy towarów masowych, głównie surowców. Na rysunku 1 zaprezentowano kolejowe przewozy towarowe przedstawione wskaźnikiem przetransportowanej masy towarów w ostatnich dziesięciu latach [4]. W 2013 roku odnotowano niewielki przyrost, jednak omawiany okres charakteryzuje się trendem spadkowym przewozów. Na tym tle lepiej prezentuje się tendencja wzrostu przewozów intermodalnych. Kolejowe przewozy intermodalne w Polsce w latach 2004-2012 przedstawione przetransportowaną masą towarów pokazano na rysunku 2 . W okresie tym charakteryzującym się trendem wzrostowym, jedynie w 2009 roku zanotowano spadek przewozów. W 2012 roku przetransportowano ponad 8 milionów ton. Tendencja wzrostu utrzymywała się również w 2013 roku. Według dostępnych danych za trzy kwartały, średnia dynamika wzrostu przetransportowanej masy w przewozach intermodalnych wyniosła $3,81 \%$.

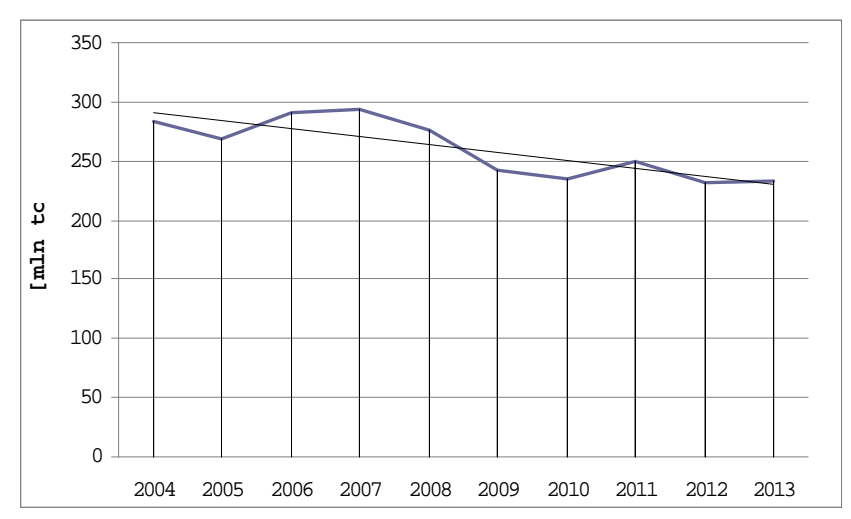

Rys. 1 - Kolejowe przewozy towarowe [4]

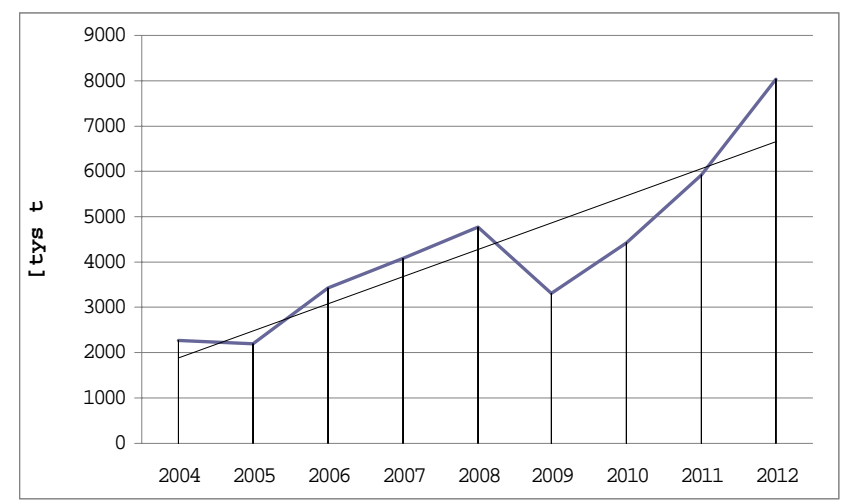

Rys. 2 - Kolejowe przewozy intermodalne [4]

W odniesieniu do całkowitej masy przetransportowanej koleja, udział transportu intermodalnego wzrastal od $0,8 \%$ w 2004 roku do 3,48\% w 2012 roku (rys. 3). Taka wartość świadczy o dużej dysproporcji pomiędzy Polską a krajami Unii Europejskiej w której średnia udziału przekracza wartość 10\%, a w przodujących krajach jest bliska wytycznych Białej księgi tj. 30\%.

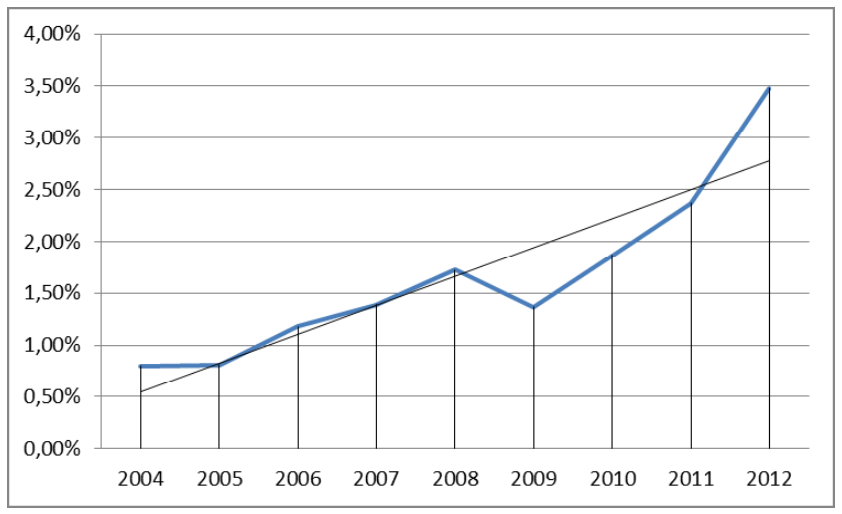

Rys. 3 - Udział przewozów intermodalnych w całkowitej masie przewozów [4]

$\mathrm{Na}$ rysunku 4 pokazano omawiany okres przewozów według przeliczeniowych jednostek TEU. Przy średniej dynamice wzrostu za ostatnie lata wynoszącej przeszło 21\% rocznie, w 2012 roku przewoźnicy uzyskali najlepszy dotychczasowy wynik kolejowych przewozów intermodalnych transportując ponad milion TEU. 


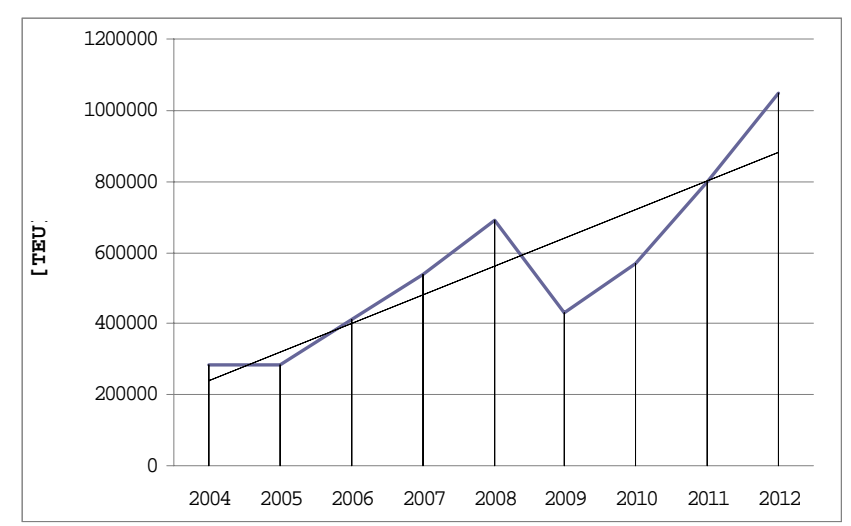

Rys. 4 - Kolejowe przewozy intermodalne wyrażone w jednostkach TEU [4]

Kolejowy transport intermodalny w Polsce opiera się na przewozie kontenerów. W 2012 roku stanowiły one $98,57 \%$ ogólnej liczby jednostek. Pozostałe $1,43 \%$ to przewozy wymiennych nadwozi samochodowych, naczep, przyczep i samochodów ciężarowych składające się na transport kombinowany [4]. A zatem, pomimo poprawiających się wskaźników dynamiki rozwoju transportu intermodalnego, typowy transport kombinowany kolejowo drogowy nadal stanowi jedynie margines przewozów.

\section{INFRASTRUKTURA}

Istotnym technicznym parametrem linii kolejowych decydującym o eksploatacji pojazdów transportu kombinowanego jest zarys skrajni [5]. W zależności od rozwiązania systemu transportu kombinowanego i transportowanych jednostek ladunkowych, wymagane są powiększone skrajnie: GC stosowana na nowych liniach lub co najmniej GB1 zalecana do wprowadzenia podczas modernizacji linii. Obecnie, między innymi z powodu skrajni ładunku, zorganizowanie przejazdu kombinowanego podlega procedurom przejazdu specjalnego.

Drugim ważnym parametrem jest dopuszczalna prędkość pojazdów. W większości przypadków tabor towarowy przystosowany jest do maksymalnej prędkości $120 \mathrm{~km} / \mathrm{h}$ i teoretycznie umożliwia uzyskanie średnich prędkości realizowanych przewozów na poziomie umożliwiającym rywalizację $\mathrm{z}$ transportem drogowym.

Według stanu na koniec 2012 roku, PKP PLK zarządzały liniami kolejowymi o długości $19191 \mathrm{~km}$ i o długości torów $36076 \mathrm{~km} \mathrm{[3].} \mathrm{Z} \mathrm{tego} 43 \%$ oceniono jako dobre, czyli eksploatowane zgodnie $\mathrm{z}$ założonymi parametrami podlegające wyłącznie zabiegom konserwacyjnym, 30\% jako dostateczne posiadające lokalne ograniczenia prędkości i wymagające wymiany uszkodzonych elementów. Pozostałe $27 \%$ stanowiły tory w stanie niezadawalającym, zakwalifikowane do kompleksowej wymiany nawierzchni. Dla prędkości $120 \mathrm{~km} / \mathrm{h}$ i wyższej dosto- sowano 23,5\% długości torów. Taki stan infrastruktury od lat przyczynia się do bardzo małej średniej prędkości handlowej kolejowych przewozów towarowych. W Polsce prędkość ta nie przekracza $26 \mathrm{~km} / \mathrm{h}$ co stanowi połowę średniej prędkości w krajach Unii Europejskiej.

Kolejnym składnikiem infrastruktury decydującym o funkcjonowaniu transportu kombinowanego są terminale przeładunkowe. W Polsce funkcjonuje około trzydziestu terminali. Sa to terminale przystosowane do przeładunku kontenerów. W zakresie transportu kombinowanego mogą być wykorzystane tylko w przypadku systemów wykorzystujących standardowy załadunek pionowy lub systemów $\mathrm{z}$ załadunkiem poziomym, które mogą samodzielnie dostosować się do powierzchni terminala. Jak dotychczas w Polsce nie funkcjonuje żaden specjalistyczny terminal przystosowany do środków transportu kombinowanego, które współdziałają z aktywnymi urządzeniami zabudowanymi $\mathrm{w}$ torach i peronach.

Obecnie spółka PKP PLK, wykorzystując środki funduszy Unii Europejskiej, realizuje zadania inwestycyjne wynikające z zawartych umów międzynarodowych, między innymi umowy europejskiej o ważnych międzynarodowych liniach transportu kombinowanego i obiektach towarzyszących. Celem jest poprawa stanu technicznego infrastruktury do poziomu umożliwiającego zintegrowanie z systemem Unii Europejskiej.

\section{POLSKIE KOLEJOWE ŚRODKI TRANS- PORTU KOMBINOWANEGO}

Instytut Pojazdów Szynowych „TABOR” od lat 80 ubiegłego wieku prowadzi prace projektowe $\mathrm{i}$ badawcze nad systemami transportu kombinowanego. Pierwszym był zaprezentowany na rysunku 5 wagon kieszeniowy do transportu naczep dwu lub trzy osiowych. Wagon wyposażony był dodatkowo w odchylne podpory umożliwiające transport kontenerów. Wagony tego typu nie zostały wdrożone na szeroką skalę ponieważ większość eksploatowanych naczep samochodowych nie jest przystosowana do pionowego załadunku.

Ograniczenia takiego pozbawiony jest przystosowany do poziomego załadunku, wagon typu „ruchoma droga” (Rollende Landstrasse) przedstawiony na rysunku 6. Projekt wagonu powstał w 1997 roku. Zbudowano prototypowy wagon na którym wykonano podstawowe próby i badania. $\mathrm{Z}$ powodu braku zamówień nie wyprodukowano następnych pojazdów. W 2009 roku zmodernizowano układ biegowy oraz zoptymalizowano ostoję wagonu. Zmodernizowany wagon wykonano dla projektu przygotowania oferty handlowej uruchomienia w Polsce 


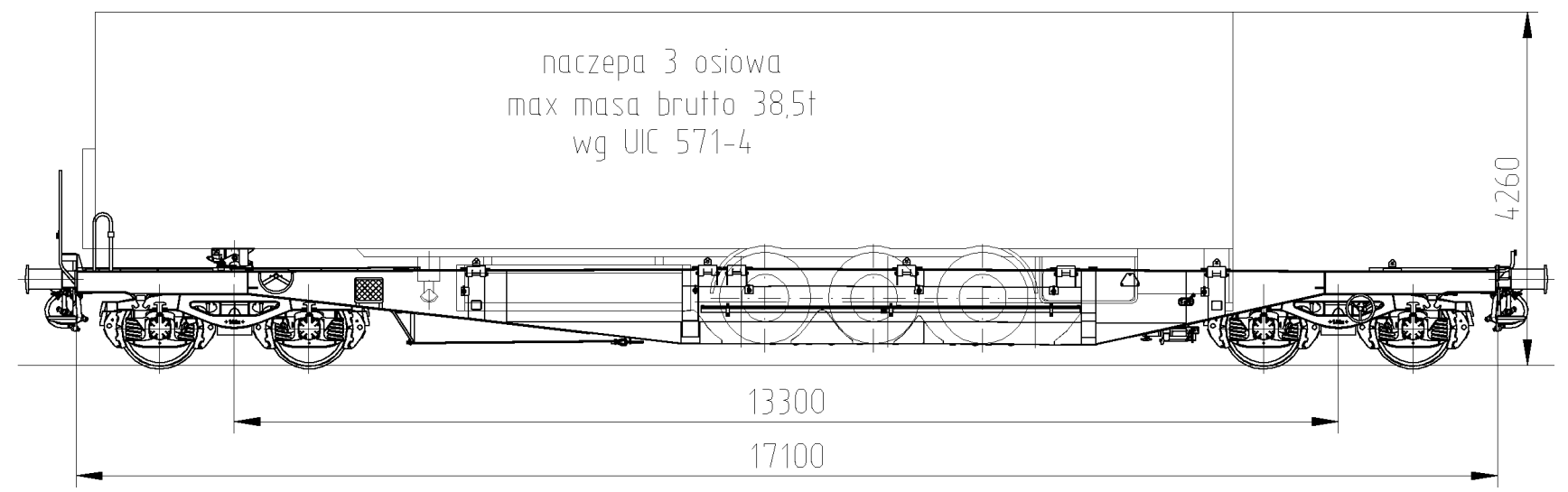

Rys. 5 - Wagon kieszeniowy [6]

przewozów pojazdów drogowych wagonami kolejowymi na najbardziej obciążonych kierunkach tranzytowych. Po wstępnych analizach dla transportu w systemie „ruchoma droga” jako najlepiej przygotowaną pod względem technicznym wytypowano linię Rzepin - Małaszewice. Kolejna próba wdrożenia wagonu do eksploatacji została zaniechana.

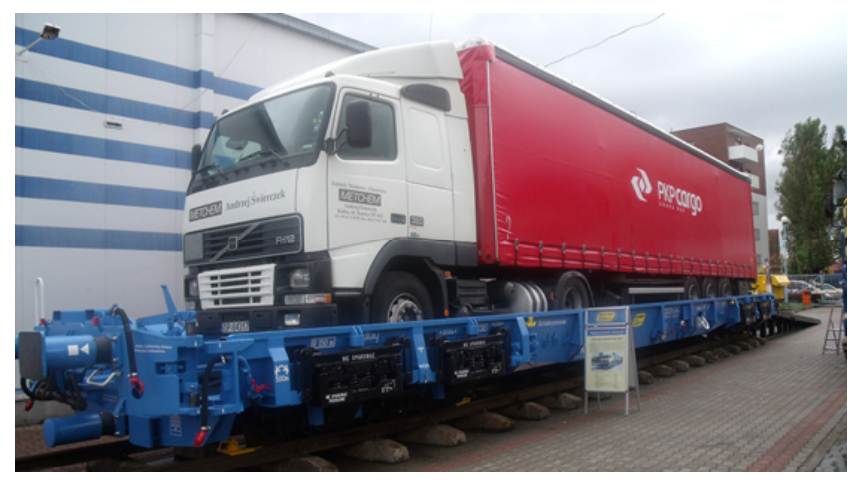

Rys. 6 - Wagon sytemu ,ruchoma droga” [6]
W IPS „TABOR” powstały polskie systemy bimodalne które umożliwiają przewóz naczep siodłowych koleją. Podstawową cechą transportu bimodalnego jest zastosowanie tradycyjnych wózków kolejowych wyposażonych w urządzenia do mocowania na nich naczep siodłowych. System bimodalny mieści się w zarysie skrajni GB1 i charakteryzuje się najmniejszą masą martwą (stosunek masy taboru do masy towaru) w odniesieniu do innych eksploatowanych systemów transportowych. Wykonano prototypy: systemu przystosowanego do prędkości ruchu $160 \mathrm{~km} / \mathrm{h}$ zbudowanego na wózkach typu $6 \mathrm{TN}$ oraz systemu na standardowych wózkach Y25 przeznaczonego do ruchu z prędkościami 100 i $120 \mathrm{~km} / \mathrm{h}$. Na rysunku 7 pokazano skład pociagu bimodalnego podczas prób.

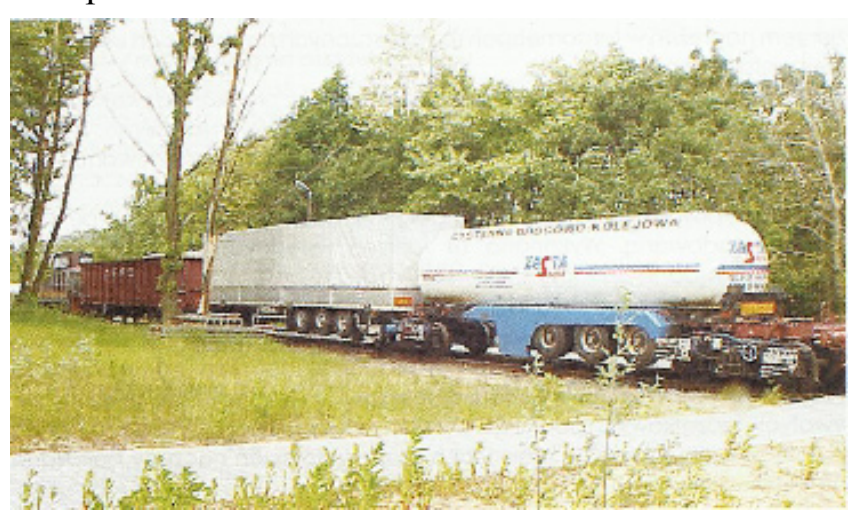

Rys. 7 - Zestaw bimodalny podczas prób nabiegania [7]

Rys. 8 - Wagon z platformą ładunkową w położeniu transportowym [8]

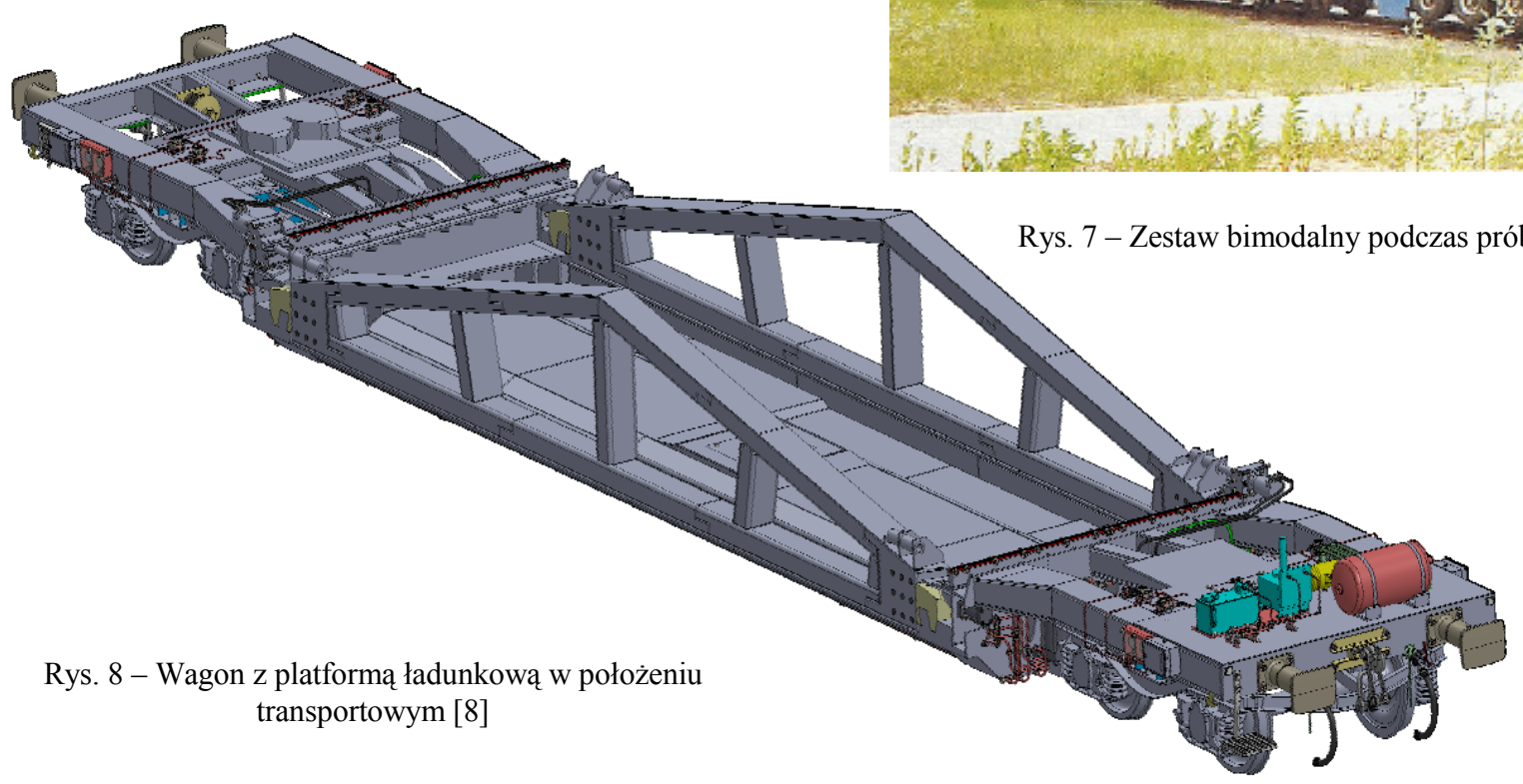


Pomimo wykonania pozytywnie zakończonych niezbędnych prób i badań zbudowanych prototypów powyżej opisanych pojazdów, żaden z nich nie został wdrożony do eksploatacji. Ponieważ część $\mathrm{z}$ zaprojektowanych pojazdów zdążyła już się zestarzeć technicznie, Instytut prowadzi prace projektowe innowacyjnych systemów do transportu naczep samochodowych.

Drugim w Polsce ośrodkiem, który podjął prace projektowe specjalnych wagonów do transportu kombinowanego jest Wojskowa Akademia Techniczna gdzie zaprojektowano trzyczęściowy wagon z obrotową platformą ładunkową [8]. Jest to nowa koncepcja opracowana na etapie teoretycznych badań modelowych. Model wagonu pokazano na rysunku 8.

\section{PODSUMOWANIE}

Pomimo bezsprzecznych zalet umożliwiających uzyskanie przewagi konkurencyjnej, transport kombinowany kolejowo-drogowy w Polsce nie został wdrożony na szeroką skalę. W procesie przejęcia masy towarowej z transportu drogowego, sektor kolejowy hamowany jest niesprzyjającym stanem organizacyjno-technicznym zarówno infrastruktury jak i posiadanych środków transportu. Pozytywnym zjawiskiem jest postępujący proces rewitalizacji infrastruktury kolejowej. Dostateczny stan techniczny linii, przy odpowiednim wsparciu samorządów i administracji państwowej umożliwi realizację przewozów wybranym systemem transportu kombinowanego.

\section{Bibliografia}

[1] Biała ksiega. Europejska polityka transportowa 2010, COM (2001)370, Bruksela 2001.

[2] Biała księga. Plan utworzenia jednolitego europejskiego obszaru transportu - dażenie do osiagnięcia konkurencyjnego i zasobooszczędnego systemu transportu, COM (2011) 144, Bruksela 2011.

[3] Raporty roczne PKP Cargo S.A. , www.pkp-cargo.pl

[4] Urzqd Transportu Kolejowego, Analizy i monitoring, www.utk.gov.pl

[5] Karta UIC 506. Przepisy dla zastosowania skrajni powiększonych $G A, G B, G C$.

[6] Archiwum IPS ,,TABOR”.

[7] Medwid M.: Polski system transportu kolejowo drogowego (bimodalnego) Typu „TABOR”. Poznań 2006.

[8] Krasoń W., Niezgoda T: Koncepcja $i$ wybrane aspekty badań wagonu kolejowego do przewozu naczep samochodów ciężarowych. Politechnika Warszawska Prace Naukowe. Transport z. 98, 2013, s.321-330.

[9] Praca zespolowa naukowo badawcza. Kierujacy praca J. Merkisz. Opracowanie modelu organizacji przewozów intermodalnych naczep siodlowych $z$ wykorzystaniem modulowego systemu transportu kombinowanego, Politechnika Poznańska, Poznań 2012. 